\title{
Spatial Estimation of Soil Erosion Using RUSLE Modeling: the Case of kaffa Zone, South western Ethiopia
}

\section{Mesfin Anteneh ( $\square$ mesfin74@yahoo.com)}

Bahir Dar University, College of Social Sciences, Department of Geography and Environmental Studies, P.O. Box 79, Bahir Dar, Ethiopia

Dereje Biru

Bonga University, College of Social Sciences, Department of Geography and Environmental Studies, P.O. Box 334, Bonga, Ethiopia https://orcid.org/0000-0002-1421-9826

\section{Research Article}

Keywords: soil erosion, RUSLE, GIS, kaffa zone, Ethiopia

Posted Date: July 27th, 2021

DOl: https://doi.org/10.21203/rs.3.rs-753720/v1

License: (c) (1) This work is licensed under a Creative Commons Attribution 4.0 International License. Read Full License 


\section{Abstract}

This research was administered to spatially predict the soil loss rate of kaffa zone using model estimate and GIS. Revised Universal Soil Loss Equation (RUSLE) adapted to Ethiopian conditions was accustomed estimate potential soil losses by utilizing information on rainfall erosivity $(R)$ using interpolation of rainfall data, soil erodibility (K) using DSMW soil map, vegetation cover (C) using Sentinel-2A satellite images, topography (LS) using Digital Elevation Model (DEM) and conservation practices (P) using DEM and satellite images. supported the analysis, the mean and total annual soil loss potential of the study area was 30 tons ha1 year-1 and 36264.5tons ha-1 year-1, respectively. The result also showed that about 2.89, 8.02, 15.31 and $73.78 \%$ of the study area were classified a slight, moderate, high and very high with values ranging 0 to 15,15 to 50,50 to 200 , and $>200$ tons ha-1 year-1, respectively. The study demonstrates that the RUSLE using GIS and RS provides great advantage to spatially analyze multi-layer of knowledge. The expected amount of soil loss and its spatial distribution could facilitate sustainable land use and management.

\section{Introduction}

The worldwide annual rate of eroding from agricultural land ranges from 22 to 100 t ha-1 and declines in productivity the maximum amount as 15-30\% annually(Morgan,2005). consistent with Morgan(2005), soil erosion costs the US economy between US\$30 billion and US\$4 billion annually associated with on-site (cost of production and production loss) and of-site (pollution and sedimentation of downstream water resources) effects of wearing away.

Soil erosion could be a common phenomenon within the east Africa highlands, where it causes widespread soil degradation (Gachene, 1995; Vaezi et al., 2007). Especially ,in ethiopia highlands are vulnerable to severe erosion (Bewket and Tefreri,2009;Gelagy and Minale,2016;Haregeweyn et al.,2017) due to extreme deforestation ,rugged topography ,historical settellement,burning of crop residue, exploitative varieties of agriculture and improper/inappropriate land management practices (Bewket and Teferi, 2009; Reusing et al., 2000; Hurni et al., 2015).

Several studies reported that majority of cultivated lands within the highlands of Ethiopia have beyond the tolerable soil loss (TSL) rate, which is between 5 to11 t ha-1 yr-1 (Moges and Bhat, 2017; Gashaw, 2018; Renard et al.,1997). Unless the present soil loss rate is averted, it will hamper agricultural production and economic development (Wischmeier and Smith, 1978; Blanco and Lal, 2008).Water-induced wearing has also caused sedimentations of water and power supply reservoirs (Wolancho, 2012). Moreover, eroding was also affecting the standard of potable, which required significant investment for water treatment services.

The severe soil erosion and its environmental and socioeconomic impacts warrant investigating different land and water management practices that will reduce erosion. Such practices include intensive cultivation, extensive cultivation ,filter strip ,tracing ,stone or soil bunds ,agro-forestation and area enclosure (Betrie et al.,2011;Tamene et la.,2017).Although several models exist to estimate erosion, the Revised Universal Soil Loss Equation (RUSLE) model (Renard et al., 1997) is useful in identifying erosion hot spot areas and suggesting appropriate conservation measures in data scare areas like the Ethiopian highlands. Since direct field measurements of erosion at permanent research or experimental stations using runoff plots with the know area, slope gradient slope length , and soil type could give reliable runoff and soil loss (Hurni et al.,2010) for experimental purposes, however, it is costly, labor-intensive, and time consuming (Alemayehu\& Alamirew,2012).

Soil erosion and land degradation is additionally becoming a significant challenge for food production within the kaffa zone. Rapid increase population growth, cultivation on steep slopes, clearing of vegetation, and overgrazing are the most factors that 
accelerate soil erosion and land degradation within the study area.Therefore, the target of the study was to assess soil loss rate and identify hot spot areas using USLE of kaffa zone, in central Ethiopia.

\section{Study Area}

This study was conducted in Kaffa Zone which is located between $6^{\circ} 24^{\prime}$ to $8^{\circ} 13^{\prime}$ North latitude and $35^{\circ} 30^{\prime}$ to $36^{\circ} 46^{\prime}$ East longitude in South Western part of South, Nation, Nationalities and Peoples Region. The Zone has a total area of 10,602.7 km2 which accounts $7.06 \%$ of the total area of the region. Administratively, Kaffa Zone is divided into twelve districts and has three conventional climatic zones based on variations in altitude and temperature. These are highland (2500 - $3000 \mathrm{~m}$ a.s.l), midland (1500 - $2500 \mathrm{~m}$ a.s.l) and lowland (500 - $1500 \mathrm{~m}$ a.s.I) (KZBoFED, 2014). Out of the total area of the Zone, highland, midland and lowland cover $11.6 \%, 59.5 \%$ and $28.9 \%$. The mean annual temperature of the area ranges $10.1{ }^{\circ} \mathrm{C}-27.5^{\circ} \mathrm{C}$. The warmest months are February, March and April while the coldest months are July and August. According to the meteorological data obtained from the Zone, the annual rainfall ranges from 1001-2200mm (KZBoFED, 2014). Kaffa Zone is a part of the South West Ethiopian regions which receive the highest amount of rainfall. This is attributable to the presence of the evergreen forest cover on top of the windward location to the moist monsoon winds.

\section{Methodology}

The overall methodology involved the utilization of the RUSLE during a GIS environment with factors obtained from meteorological stations, soil map, topographic map, Satellite Images and DEM as shown in equation 1, Figure 2. Individual GIS layers were built for every think about the RUSLE and combined by cell-grid modeling procedures in ArcGIS to predict soil loss in a very spatial domain (Eastman, 1999). Annual soil loss rate determined by multiplying the respective RUSLE factor values interactively using "Spatial Analyst Tool Map Algebra Raster Calculator" in ArcGIS 10.5 environment as shown equation (1) adopted from the recommendation of Hurin (1985) and Gebreselassie(1996). Soil loss potential of the study area was then categorized into different severity classes adapted from FAO (1984), like slight (0-15 tha-1 $\left.\mathrm{yr}^{-1}\right)$, Moderate $\left(15-50 \mathrm{t} \mathrm{ha}^{-1} \mathrm{yr}^{-1}\right.$ ), High (50-200 tha-1 $\left.\mathrm{yr}^{-1}\right)$, Very high ( $\left.>200 \mathrm{t} \mathrm{ha}^{-1} \mathrm{yr}^{-1}\right)$.

$A=R \times K \times L S \times C \times P$ ...Equation (1)

Where $A$ is that the annual soil loss (metric tons ha- 1 year- 1 ); $R$ is that the rainfall erosivity factor [MJ mm $h-1$ ha1 year- 1$]$; $K$ is soil erodibility factor [metric tons ha-1 MJ -1 mm-1]; LS = slope length factor (dimensionless); $\mathrm{C}$ is land cover and management factor (dimensionless) and $\mathrm{P}$ is conservation practice factor (dimensionless). Selected GPS points were used for checking and validation of results. All the maps were geo-referenced with Universal Transverse Mercator (UTM) coordinate system.

Table1.Summary of data types and their sources.

\begin{tabular}{|c|c|c|}
\hline Data Type & sources & Purpose \\
\hline Rainfall data(1980-2019) & NMA & To develop Rainfall erosivity factor (R-value) \\
\hline Spot6 satellite image & & To develop LULC then from LULC to dervive the crop factor (C) \\
\hline with $1.5 \mathrm{~m}$ resouition & USGS & and conservation practice factor $(\mathrm{P})$ \\
\hline $\begin{array}{l}\text { \&clay) } \\
\text { SRTMDEM with } 30 \mathrm{~m}\end{array}$ & DSMW & To develop Soil erodibility factor (K value) \\
\hline resolution & USGS & $\begin{array}{l}\text { to develop Slope length and slope gradient factor (LS value) \& } \\
\text { conservation practice factor (P value) }\end{array}$ \\
\hline Ground truth data & $\begin{array}{l}\text { Field } \\
\text { servey,2021 }\end{array}$ & $\begin{array}{l}\text { Selected GPS points were used for checking and validation of } \\
\text { results }\end{array}$ \\
\hline
\end{tabular}

Table 2: Software and materials employed in the study 


\begin{tabular}{ll}
\hline Software used & Purpose \\
\hline ERDAS IMAGIN & Image processing and data analysis \\
2015 & Data base creation, land use/cover, Raster Calculator, map preparation \\
ArcGIS 10.5 & \\
& For collecting of GCP points which were created at random for the study area using Arc \\
GPS(Global & GIS 10.5 used mainly for accuracy assessment area measurement \\
Position & \\
\hline
\end{tabular}

\section{Results And Discussion}

\subsection{Determination of Soil Loss Factors}

\subsubsection{Rainfall Erosivity Factor}

The erosivity factor $\mathrm{R}$ was calculated using the equation given in Hurini (1985) adapted for the Ethiopian condition which has been derived from spatial regression analysis (Helldén, 1987). (Eq.2). Other studies have also reported successfully using the equation (Amsalu et al., 2014; Asmamaw\& Mohammed, 2019; Bewket \& Teferi, 2009; Gashaw et al., 2018; Meshesha et al., 2012; Shiferaw, 2011; Wolka et al., 2015).The R-factor is given by a regression equation as:

$R=-8.12+0.562 P \ldots$ Equation (2)

Where $\mathrm{R}$ is the erosivity factor and $\mathrm{P}$ is the mean annual rainfall $\left(\mathrm{mm}_{\mathrm{year}}{ }^{-1}\right)$.

To compute $\mathrm{R}$ factor, mean annual rainfall of thirty six years (1980 - 2019) was collected from 19 metrological stations were found within the zone boundary. After calculating average 39 years of rainfall for each station, the R factor was computed using the above formula and converted in to raster surface using IDW (Inverse Distance weighted) interpolation methods in ArcGIS software (Figure 3).

\subsubsection{Soil Erodibility Factor}

The soil erodibility factor $(K)$ measures the susceptible soil types and their particles to detachment and transport by rainfall and runoff. The $\mathrm{K}$ factor influenced by soil texture, organic matter, soil structure, and permeability of the soil profile (Erencin et al. 2000). The equation provided by reference used to estimate the soil loss (Kouli et al. 2009).

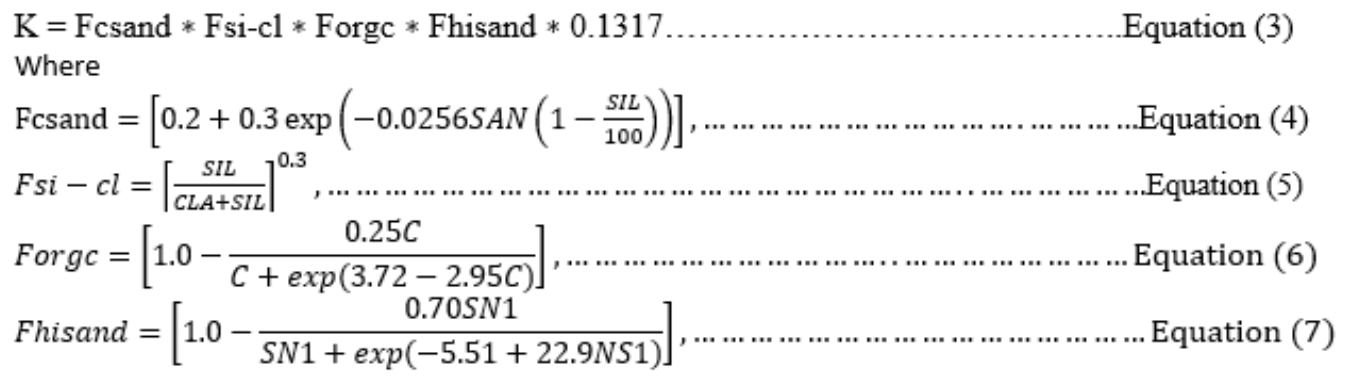

Where SAN, SIL and CLA are \% sand, silt and clay, respectively; C is the organic carbon content; and SN1 sand content subtracted from 1 and divided by 100 . Fcsand=low soil erodibility factor for soil Fsicl=low soil erodibility factor with high clay to silt ratio. Forgc $=$ factor that reduces soil erodibility for soil with high organic content. Fhisand=factor that reduces soil erodibility for soil with high sand content (Table2 and Figure 4).

Table 2 .Method to calculate KUSLE value 


\begin{tabular}{ccccccccccc}
\hline $\begin{array}{c}\text { Soil } \\
\text { unit } \\
\text { symbol }\end{array}$ & $\begin{array}{c}\text { sand } \\
\text { topsoil }\end{array}$ & $\begin{array}{c}\text { silt } \% \\
\text { topsoil }\end{array}$ & $\begin{array}{c}\text { clay } \% \\
\text { topsoil }\end{array}$ & $\begin{array}{c}\text { OC } \% \\
\text { topsoil }\end{array}$ & FcSand & fcl-si & Forganic & fhisand & Kusle & $\begin{array}{c}\text { K=KUSLE } \\
* 0.1317\end{array}$ \\
\hline NE & 68.4 & 10.5 & 21.2 & 0.6 & 0.200000047 & 0.717859 & 0.96653 & 0.962738 & 0.133596 & 0.017595 \\
NE & 68.4 & 10.5 & 21.2 & 0.6 & 0.200000047 & 0.717859 & 0.96653 & 0.962738 & 0.133596 & 0.017595 \\
BE & 36.4 & 37.2 & 26.4 & 1.07 & 0.200862282 & 0.851385 & 0.761202 & 0.999948 & 0.130167 & 0.017143 \\
BE & 36.4 & 37.2 & 26.4 & 1.07 & 0.200862282 & 0.851385 & 0.761202 & 0.999948 & 0.130167 & 0.017143 \\
JC & 39.6 & 39.9 & 20.6 & 0.65 & 0.200677792 & 0.882603 & 0.957979 & 0.999897 & 0.169659 & 0.022344 \\
VC & 22.4 & 24.5 & 53 & 0.69 & 0.203952351 & 0.707879 & 0.949806 & 0.999997 & 0.137127 & 0.01806 \\
\hline
\end{tabular}

\subsubsection{Slope Length and Slope Steepness Factor}

The $30 \mathrm{~m}$ spatial resolutions DEM (digital elevation model) were accustomed generate slope by using "Spatial Analyst Tool Surface Slope" in ArcGIS 10.5 environment. The flow accumulation and slope steepens were computed from DEM using Arc GIS. Flow Accumulation was derived from hydrologically corrected DEM after conducting FILL and Flow Direction processes by Arc Hydro tools, GIS software. Flow accumulation and slope maps were multiplied by using spatial analyst tool map algebra raster calculator in arc GIS to calculate and map the slope length (LS factor) as shown in equation (8) and defined by Wischmeier and Smith (1978).

LS $=(\text { Flow Accumulation } \star \text { Cell size/22.13 })^{0.4} *(\text { Sin slope/0.896 })^{1.3} \ldots \ldots \ldots \ldots \ldots . . .$. Equation $(8)$

Where cell size represents the field slope length and 22.13 is the length of the research field plot.

\subsubsection{Crop cover and management (C factor)}

The cover management factor represents the ratio of soil loss under a given cover there to of the bottom soil (Morgan, 1994). Land cover includes a profound impact on erosion and deposition. Surface cover, like vegetation or plant residue may intercept and reduce raindrop erosivity, increase infiltration, bog down runoff and reduce transporting capacity of water flow. The land use /land cover map was used for the estimation of C-value. The raster land use/land cover map was converted to a vector format and a corresponding C-value was assigned to every land use classes supported cover values proposed by various authors, but mainly Hurni (1985)(Table3).Finally, using reclassification and vector to raster conversion the land use/ land cover map was converted to $\mathrm{C}$ factor map (Figure 6).

Table 3 Land use, area coverage, and cover management factor for the study area

\begin{tabular}{lllll}
\hline LU/LC Categories & Area (ha) & Area (\%) & C -factor Value & Reference \\
\hline water body & 823.150507 & 0.039772 & 0 & (Erdogan et al.,2006) \\
Forestland & 434825.211 & 21.0094 & 0.01 & Hurni (1985a,1985b) \\
Grassland & 371155.181 & 17.93306 & 0.1 & Hurni (1985) \\
Bare Land & 258688.907 & 12.49904 & 1 & Hurni (1985) \\
Cropland & 995845.13 & 48.11613 & 0.15 & (Hurni 1985;Truneh\&Ayalew,2015) \\
\hline Settlement & 8332.59112 & 0.402605 & 0.15 & Hurni (1985) \\
\hline
\end{tabular}

\subsubsection{Erosion management practice ( $P$ factor)}

The conservation practices factor ( $p$-values) reflects the consequences of practices which will reduce the number and rate of the water runoff and thus reduce the number of abrasion. AS data were lacking on permanent management factors and there have been no management practices, we used the p-values suggested by Bewket and Teferi(2009);Wischmeir and Smith(1978);Shi, Cai, Ding, Li, Wang and Sun (2002) that consider only two varieties of land uses (agricultural and nonagricultural) and land slopes. Thus, the agricultural lands were classified into six slope categories and assigned P-values while all non-agricultural lands are assigned a P-value of 1 (Table4 and Figure 7). 
Table 4. Conservation practices factor (P-value)

\begin{tabular}{llll}
\hline Land use & Slope category (\% & P factors & Reference \\
\hline Cultivated land & $0 \_5$ & 0.1 & (Wischmeier and Smith , 1978; \\
& 5_10 & 0.12 & Hurni ,1985; \\
& $10 \_20$ & 0.14 & Bewket and Teferi ,2009; \\
& $20 \_30$ & 0.19 & Gelagay and \\
& $30 \_50$ & 0.25 & Minale ,2016) \\
& $50 \_100$ & 0.33 & \\
Other land use & All & 1 & \\
\hline
\end{tabular}

\subsection{Soil Loss Estimation and Prioritization for Soil Conservation Planning}

All the layers of the RUSLE factors viz. R, K, LS, C and P with $1.5 \times 1.5$ m output cell size were generated within the GIS environment and were crossed to obtained the product, which provides annual soil loss (A) for the kaffa zone. These values gave annual soil loss per hectare per year at pixel level. Supported the analysis, the mean annual soil loss of the study area was found to be 30 ton ha ${ }^{-1}$ year ${ }^{-1}$ with a range of 0 to 36264.6 ton ha $^{-1}$ year-1.

The finding of this study is in agreement with the findings of previous studies tired the other parts of the country. For instance, in line with Hurni et al. (2010), reported eating away from cultivation land in Ethiopian highlands reaches 130 - 170 ton ha-1 year-1. Bewket and Teferi (2009), have found mean annual soil loss starting from 7-243 t/ha/yr for a catchment within the Blue Nile basin while Hawando (1995), found the annual soil loss of Ethiopia highlands ranges from 16-300 ton ha-1 year ${ }^{-1}$ from pasture ranges and cultivated fields.

As demonstrated in Table 5, the spatial patterns of annual average soil loss distribution were grouped into four erosion intensity classes, which were adapted from FAO (1984), like slight (0-15 tha-1 $\left.\mathrm{yr}^{-1}\right)$, Moderate (15-50 $\left.\mathrm{t} \mathrm{ha}^{-1} \mathrm{yr}^{-1}\right)$, High $\left(50-200 \mathrm{t} \mathrm{ha}^{-1} \mathrm{yr}^{-1}\right.$ ), Very high ( $>200 \mathrm{t} \mathrm{ha}^{-1} \mathrm{yr}^{-1}$ ).Accordingly, about $712529.87 \mathrm{ha}(73.78 \%$ ) of the study area experiences Slight rates of soil erosion, whereas areas affected by Moderate and High rates of soil loss encompass $147848.63 \mathrm{ha}(15.31 \%)$ and $77451.04 \mathrm{ha}(8.02 \%)$ respectively. In total, areas affected by Very high soil loss rates cover approximately27946.38ha (2.89\%) (Table 5). This implies that most of the total soil loss was generated from the small areas which experiences high erosion rates (Fig.8)

It will be observed from the assigned class that the various priority areas contributed differently to the entire erosion rate. For example, priority class $1^{\text {st }}$ covers $2.89 \%$ of the whole the study area, $2^{\text {nd }}, 3$ rdand $4^{\text {th }}$ cover combined $97.11 \%$ the study area. These priority classes highly contributed to soil loss (Shiferaw, 2011).

Table 5. Annual soil loss rate, severity class and priority areas in the Kaffa Zone

\begin{tabular}{llllrl}
\hline Class & Soil loss (t ha1 yr1 ) & Description & Area(ha) & Area (\%) & Priority classes \\
\hline I & $0-15$ & Slight & 712529.87 & 73.78 & 4 th \\
II & $15-50$ & Moderate & 147848.63 & 15.31 & $3 \mathrm{rd}$ \\
III & $50-200$ & High & 77451.04 & 8.02 & $2 \mathrm{nd}$ \\
IV & $>200$ & Very high & 27946.38 & 2.89 & $1 \mathrm{st}$ \\
\hline
\end{tabular}

\section{Conclusion}

The severity assessment of erosion GIS - based RUSLE equation considering rainfall, soil, DEM, land use, and land cover. The erosion rate categorized into four classes supported its severity, and $73.78 \%$ of the regions found under severe $\left(0-15 \mathrm{tha}^{-1} \mathrm{yr}^{-1}\right)$ $2.89 \%$ of areas remained during a Very high. This show area with high elevation together with prompt rainfall liable to eating away. The anticipated severity can provide a basis for conservation and planning processes at the decision-makers. The regions with high to very severe wearing warrant special priority and control measures. While this model forms a basis on mapping and 
prediction using remote sensing and GIS-based analysis for vulnerability zones, such studies suggested for conservation and refining the model within the future.

\section{Declarations}

\section{Ethics approval and consent to participate}

Informed consent was obtained from all student participants involved in the study. All participants freely agreed to participate in the study without reservation.

\section{Funding}

The authors are not received any fund.

\section{Consent for publication}

Consent to publish individual data in any form was obtained from the participants interviewed.

\section{Availability of data and materials}

Not applicable' for that section

\section{Competing interest}

The authors declare no competing interests.

\section{Authors' contributions}

Mesfin Anteneh and Dereje Biru conceived and designed the work validated the method section. Both authors participated in the analysis, validation and writing of the paper. Both authors read and approved the final manuscript.

\section{Acknowledgment}

The authors are highly indebted to all secondary data provider organizations. The authors are also grateful to those individuals who assist in different stages of this work. We acknowledge the comments from anonymous reviewers.

\section{References}

Alemayehu, G., \& Alamirew, T. (2012). Testing and Validation of the Revised Universal Soil Loss Equation (RUSLE-2) at the Twin Catchments of Gununo, Wolaita. PhD diss., Haramaya University.

Amsalu T, Mengaw A. GIS-based soil loss estimation using rusle model: the case of jabi tehinan woreda, ANRS, Ethiopia. Nat Resour. 2014;19:2014.

Asmamaw, L. B., \& Mohammed, A. A. (2019). Identification of soil erosion hotspot areas for sustainable land management in the Gerado catchment, North-eastern Ethiopia. Remote Sensing Applications: Society and Environment, 13, 306-317.

Betrie, G. D., Mohamed, Y. A., Griensven, A. V., \& Srinivasan, R. (2011). Sediment management modelling in the Blue Nile Basin using SWAT model. Hydrology and Earth System Sciences, 15(3), 807-818.

Bewket W, Teferi E (2009) Assessment of soil erosion hazard and prioritization for treatment at the watershed level: case study in the Chemoga watershed, Blue Nile basin, Ethiopia. Land Degrade Dev 20(6): 609-622.

Bewket, W., \& Teferi, E. (2009). Assessment of soil erosion hazard and prioritization for treatment at the watershed level: case study in the Chemoga watershed, Blue Nile Basin, Ethiopia. Land Degradation \& Development, 20(6), 609-622. 
Bewket, W., \& Teferi, E. (2009). Assessment of soil erosion hazard and prioritization for treatment at the watershed level: case study in the Chemoga watershed, Blue Nile Basin, Ethiopia. Land Degradation \& Development, 20(6), 609-622.

Blanco, H., \& Lal, R. (2008). Principles of soil conservation and management (Vol. 167169). New York: Springer.

Eastman, J. R. (1999). IDRISI for windows user's guide version 32: introduction. Worcester (MA/USA): Clark University/Graduate School of Geography.

Erdogan, B., Liden, R. C., \& Kraimer, M. L. (2006). Justice and leader-member exchange: The moderating role of organizational culture. Academy of Management journal, 49(2), 395-406.

Erencin, Z., Shresta, D. P., \& Krol, I. B. (2000). C-factor mapping using remote sensing and GIS. Case study Lom SakLom Kao Thail Geogr Inst Justus-Liebig-Univ Giess Intern Inst Aerosp Surv Earth ScilTC Enschede Netherland.

FAO-UNESCO (1974) FAO/UNESCO Soil Map of the World 1:5.000.000, UNESCO, Paris. Fubelli G, Abebe B, Dramis, F, Vinci S (2008) Geomorphological evolution and present-day processes in the Dessie Graben (Wollo, Ethiopia). Catena 75: 28-37.

Gachene, C. K. K. (1995). Evaluation and mapping of soil erosion susceptibility: an example from Kenya. Soil Use and Management, 11(1), 1-4.

Gashaw, T., Tulu, T., \& Argaw, M. (2018). Erosion risk assessment for prioritization of conservation measures in Geleda watershed, Blue Nile basin, Ethiopia. Environmental Systems Research, 6(1), 1-14.

Gebreselasie, E. D. (1996). Soil erosion hazard assessment for land evaluation. Soil Conservation Research Program, University of Bern, Switzerland and the Ministry of Agriculture, Ethiopia (Doctoral dissertation, MSc Thesis, 1996: 68-82).

Gelagay, H. S., \& Minale, A. S. (2016). Soil loss estimation using GIS and Remote sensing techniques: A case of Koga watershed, Northwestern Ethiopia. International Soil and Water Conservation Research, 4(2), 126-136.

Gelagay, H. S., \& Minale, A. S. (2016). Soil loss estimation using GIS and Remote sensing techniques: A case of Koga watershed, Northwestern Ethiopia. International Soil and Water Conservation Research, 4(2), 126-136.

Haregeweyn, N., Tsunekawa, A., Poesen, J., Tsubo, M., Meshesha, D. T., Fenta, A. A., ... \& Adgo, E. (2017). Comprehensive assessment of soil erosion risk for better land use planning in river basins: Case study of the Upper Blue Nile River. Science of the Total Environment, 574, 95-108.

Haregeweyn, N., Tsunekawa, A., Poesen, J., Tsubo, M., Meshesha, D. T., Fenta, A. A., ... \& Adgo, E. (2017). Comprehensive assessment of soil erosion risk for better land use planning in river basins: Case study of the Upper Blue Nile River. Science of the Total Environment, 574, 95-108.

Hawando T (1995) The Survey of the Soil and Water Resources of Ethiopia. UNU/Toko.

Helldén, U. (1987). An assessment of woody biomass, community forests, land use and soil erosion in Ethiopia. A feasibility study on the use of remote sensing and GIS [geographical information system]-analysis for planning purposes in developing countries. Lund University Press.

Hurni H, Abate S, Bantider A, Debele B, Ludi E, et al. (2010) Land Degradation and Sustainable Land Management in the Highlands of Ethiopia.

Hurni H. Erosion-productivity-conservation systems in Ethiopia. 1985. pp 654-74.

Hurni, H. (1985). Erosion-productivity-conservation systems in Ethiopia.

Hurni, H., Abate, S., Bantider, A., Debele, B., Ludi, E., Portner, B., ... \& Zeleke, G. (2010). Land degradation and sustainable land management in the highlands of Ethiopia. 
Hurni, H., Giger, M., Liniger, H., Studer, R. M., Messerli, P., Portner, B., ... \& Breu, T. (2015). Soils, agriculture and food security: the interplay between ecosystem functioning and human well-being. Current Opinion in Environmental Sustainability, 15, 25-34.

Kouli, M., Soupios, P., \& Vallianatos, F. (2009). Soil erosion prediction using the revised universal soil loss equation (RUSLE) in a GIS framework, Chania, Northwestern Crete, Greece. Environmental Geology, 57(3), 483-497.

Meshesha, D. T., Tsunekawa, A., Tsubo, M., \& Haregeweyn, N. (2012). Dynamics and hotspots of soil erosion and management scenarios of the Central Rift Valley of Ethiopia. International Journal of Sediment Research, 27(1), 84-99.

Moges, D. M., \& Bhat, H. G. (2017). Integration of geospatial technologies with RUSLE for analysis of land use/cover change impact on soil erosion: case study in Rib watershed, north-western highland Ethiopia. Environmental Earth Sciences, $76(22), 765$.

Morgan RP. Soil erosion and conservation. New York: Wiley; 2005

Morgan, R. M., \& Hunt, S. D. (1994). The commitment-trust theory of relationship marketing. Journal of marketing, 58(3), 20-38.

Renard, K. G. (1997). Predicting soil erosion by water: a guide to conservation planning with the Revised Universal Soil Loss Equation (RUSLE). United States Government Printing.

Reusing, M., Schneider, T., \& Ammer, U. (2000). Modelling soil loss rates in the Ethiopian Highlands by integration of high resolution MOMS-02/D2-stereo-data in a GIS. International Journal of remote sensing, 21(9), 1885-1896.

Shi, Z. H., Cai, C. F., Ding, S. W., Li, Z. X., Wang, T. W., \& Sun, Z. C. (2002, May). Assessment of erosion risk with the rusle and Gis in the middle and lower reaches of Hanjiang River. In 12th ISCO Conference (Vol. 2631).

Shiferaw, A. (2011). Estimating soil loss rates for soil conservation planning in the Borena Woreda of South Wollo Highlands, Ethiopia. Journal of Sustainable Development in Africa, 13(3), 87-106.

Vaezi, A. R., Sadeghi, S. H. R., Bahrami, H. A., \& Mahdian, M. H. (2008). Modeling the USLE K-factor for calcareous soils in northwestern Iran. Geomorphology, 97(3-4), 414-423.

Wischmeier, W. H., \& Smith, D. D. (1978). Predicting rainfall erosion losses: a guide to conservation planning (No. 537). Department of Agriculture, Science and Education Administration.

Wolancho, K. W. (2012). Watershed management: an option to sustain dam and reservoir function in Ethiopia. Journal of Environmental Science and Technology, 5(5), 262-273.

Wolka, K., Tadesse, H., Garedew, E., \& Yimer, F. (2015). Soil erosion risk assessment in the Chaleleka wetland watershed, Central Rift Valley of Ethiopia. Environmental Systems Research, 4(1), 1-12.

Zerihun, M., Mohammedyasin, M. S., Sewnet, D., Adem, A. A., \& Lakew, M. (2018). Assessment of soil erosion using RUSLE, GIS and remote sensing in NW Ethiopia. Geoderma regional, 12, 83-90.

\section{Figures}




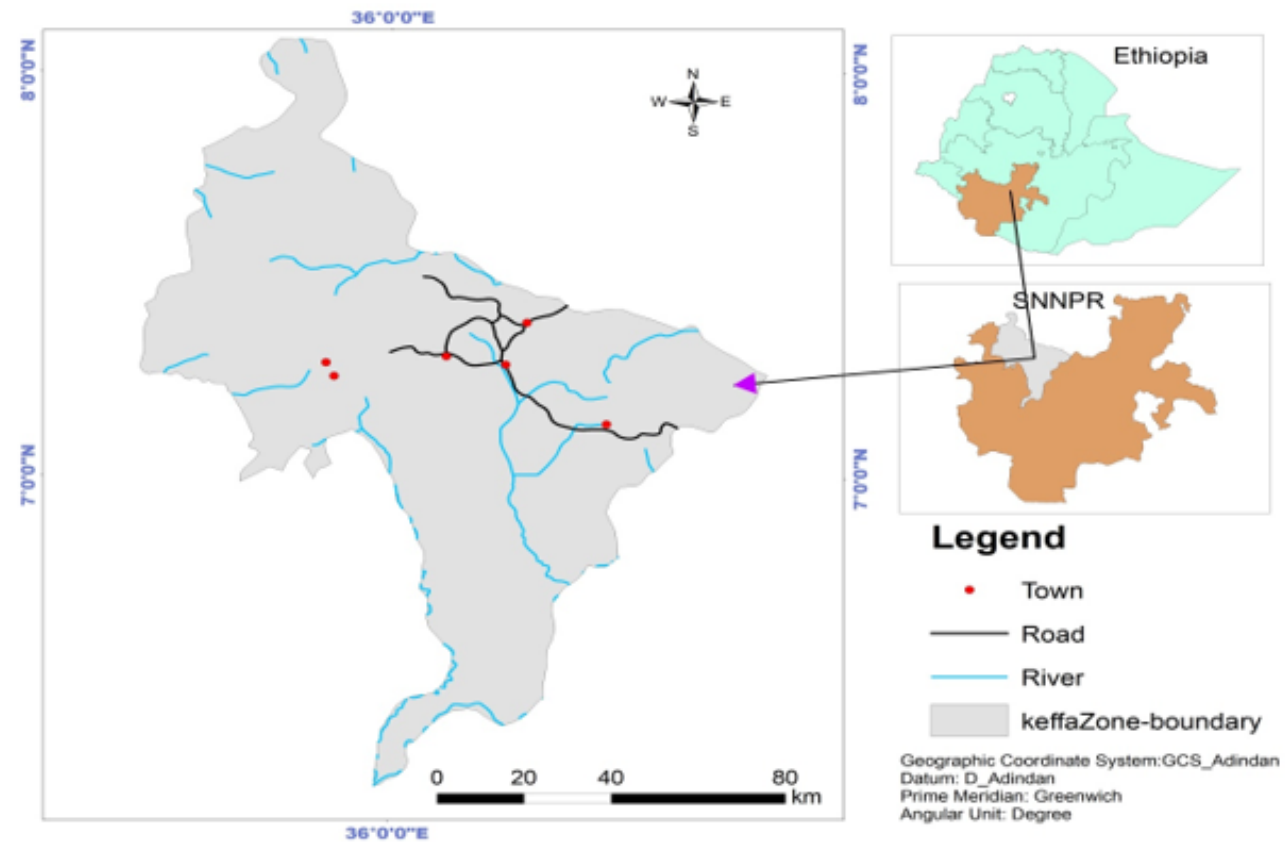

Figure 1

Location map of Kaffa Zone.

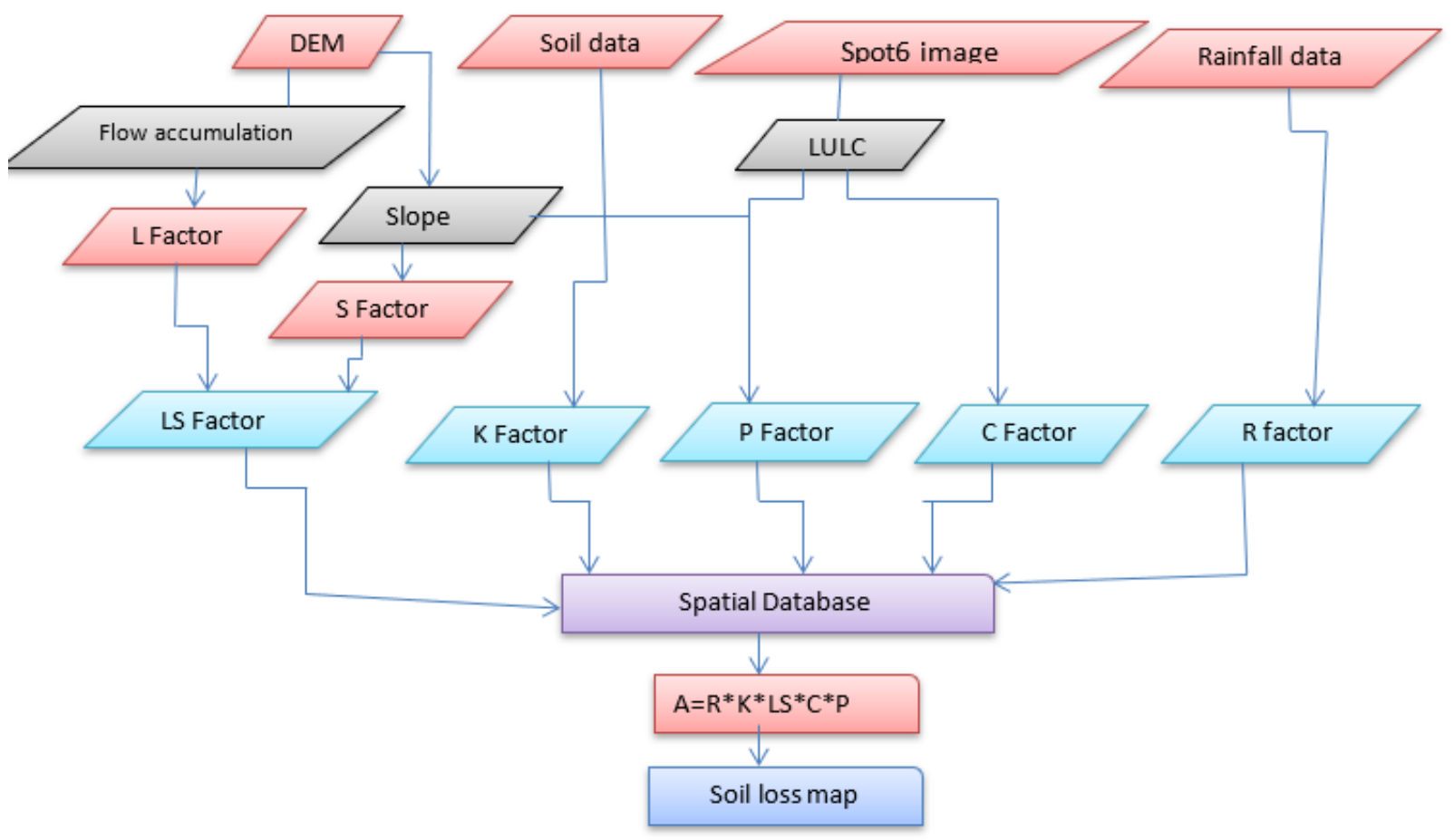

\section{Figure 2}

Soil Loss (Erosion) Estimation Flow Chart using RUSLE Model 


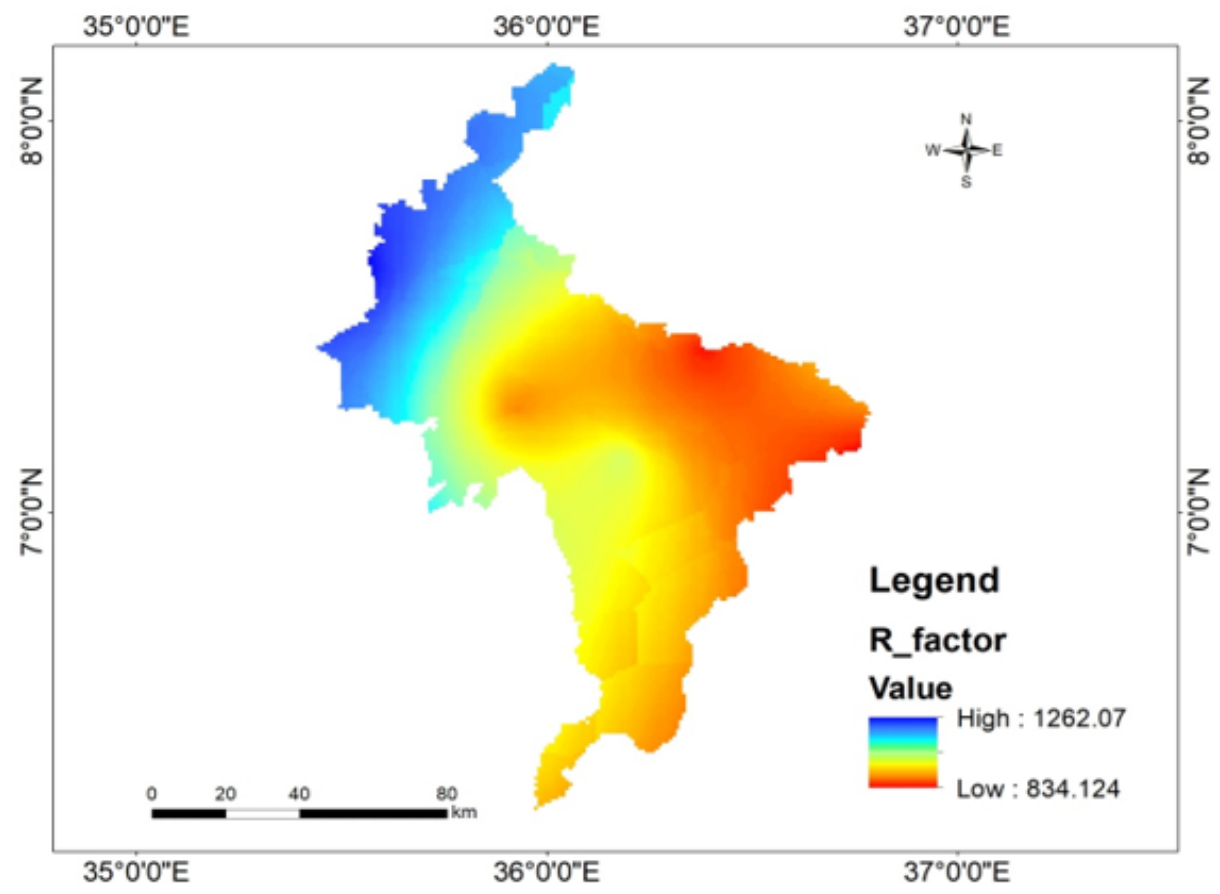

\section{Figure 3}

Map of Rainfall Erosivity Factor generated from the mean annual rainfall of Kaffa Zone

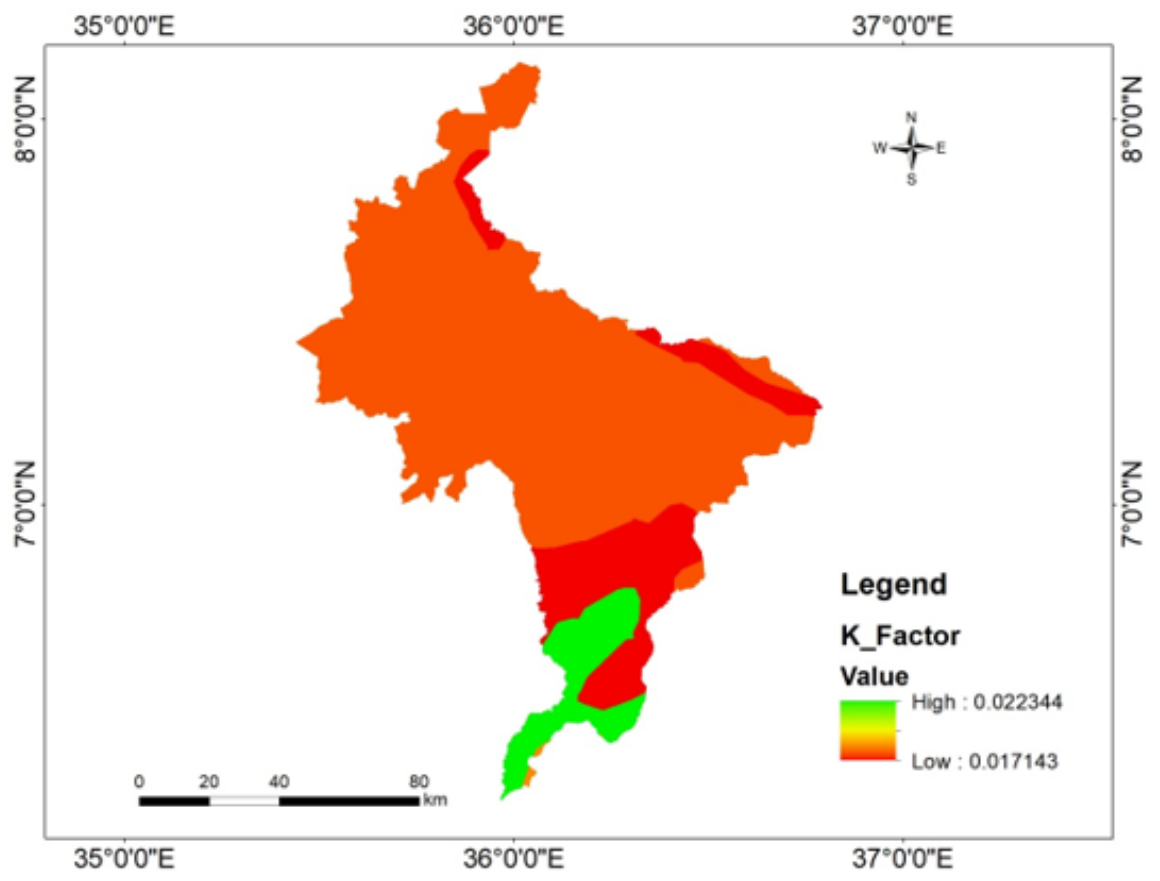

Figure 4

Map of Soil Erodibility Factor generated from the DSMW for Kaffa Zone 


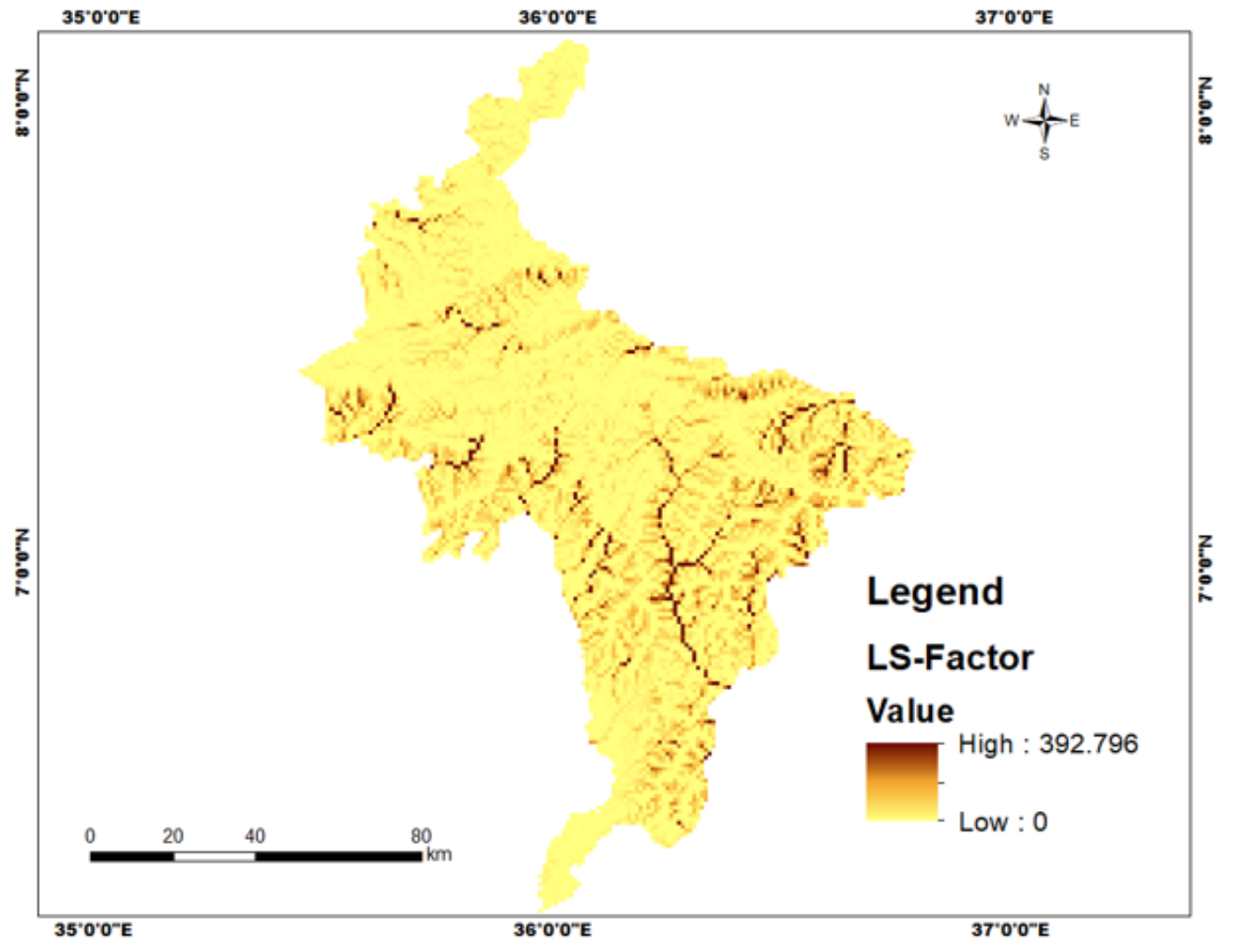

Figure 5

Map of slope length and steepness (LS) factor generated from the DEM and topographic map of the study area.

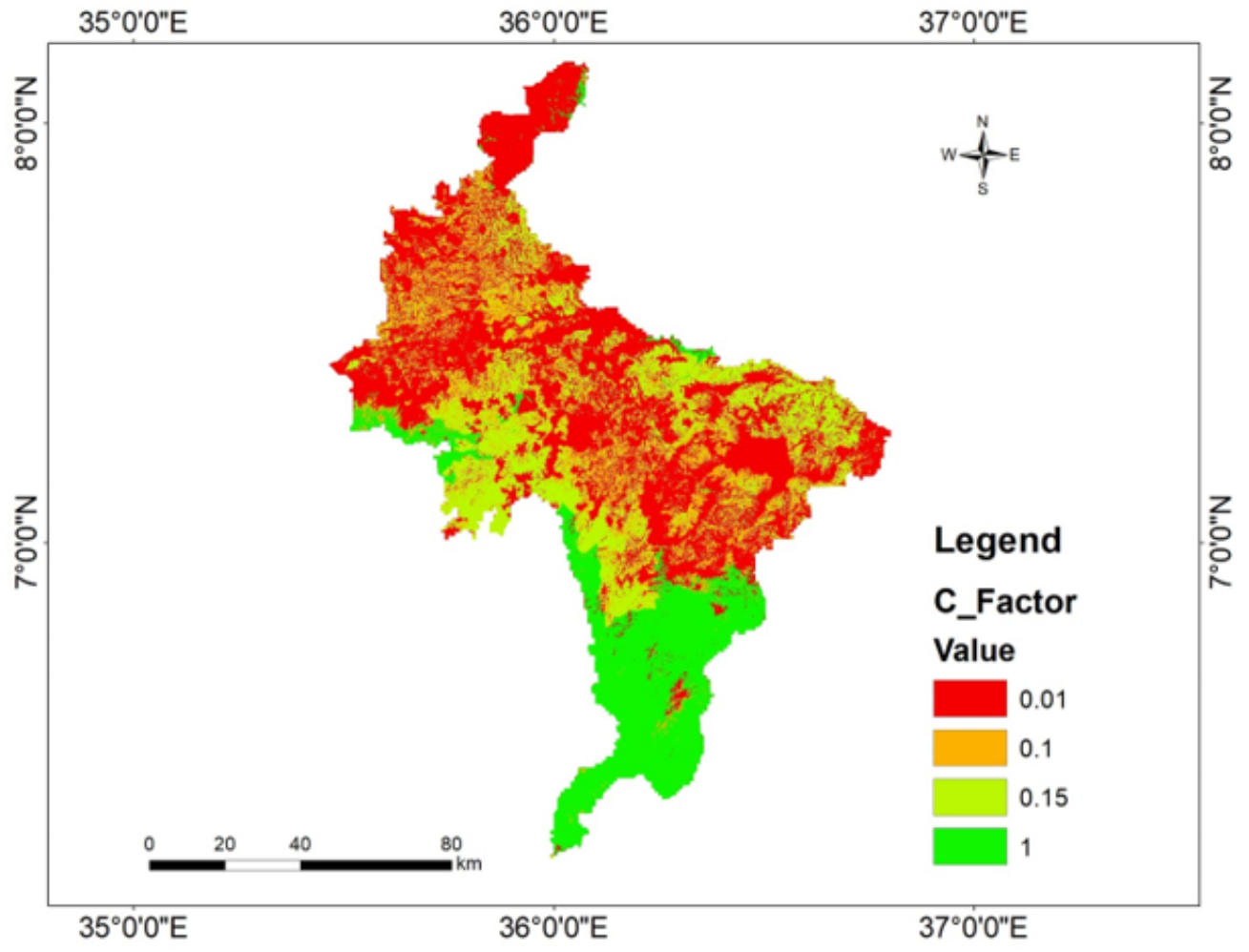

Figure 6

Map of Crop cover and management ( $C$ factor) generated from LULC 


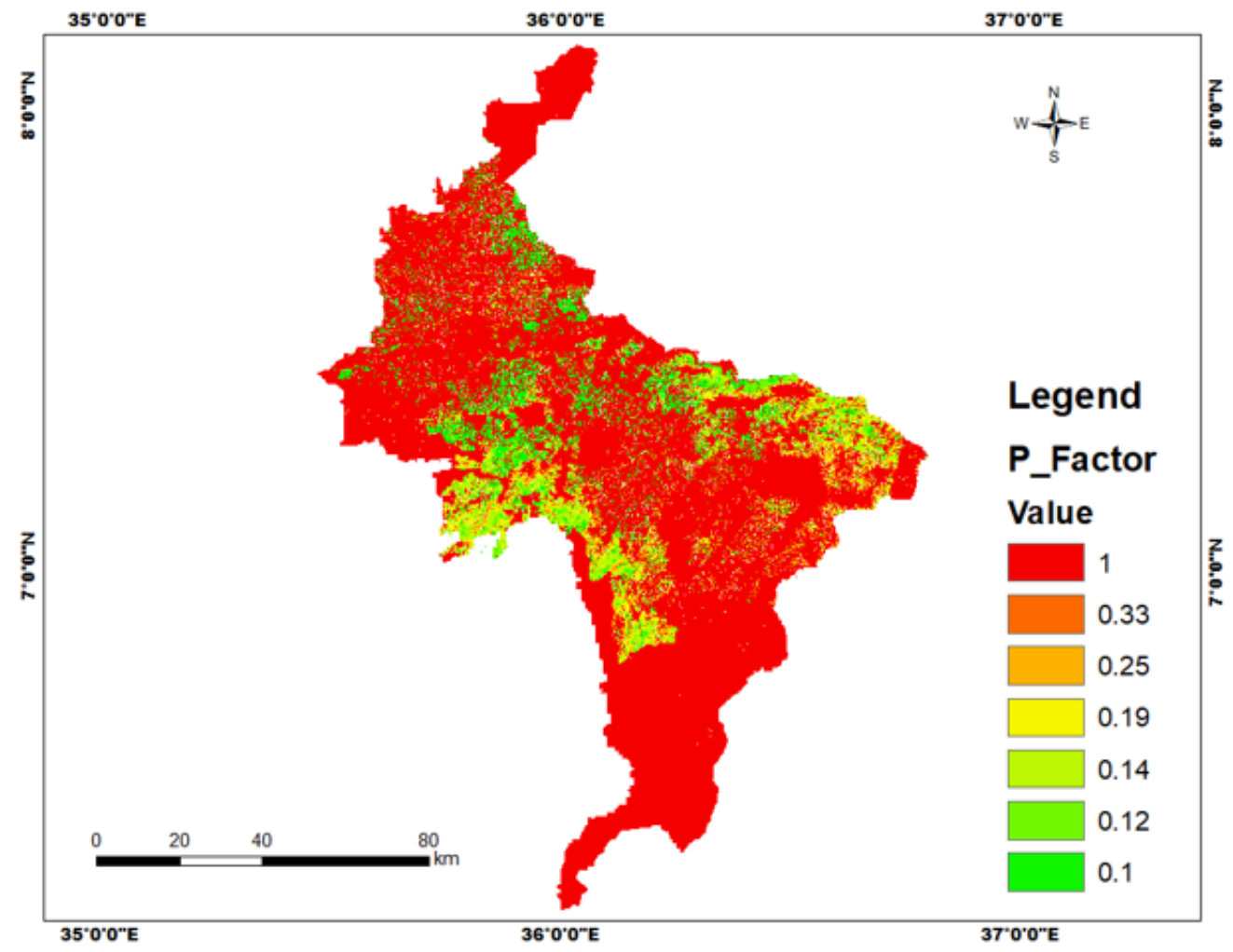

Figure 7

Map of conservation practices factor ( $p$-values) generated from LULC \&slope

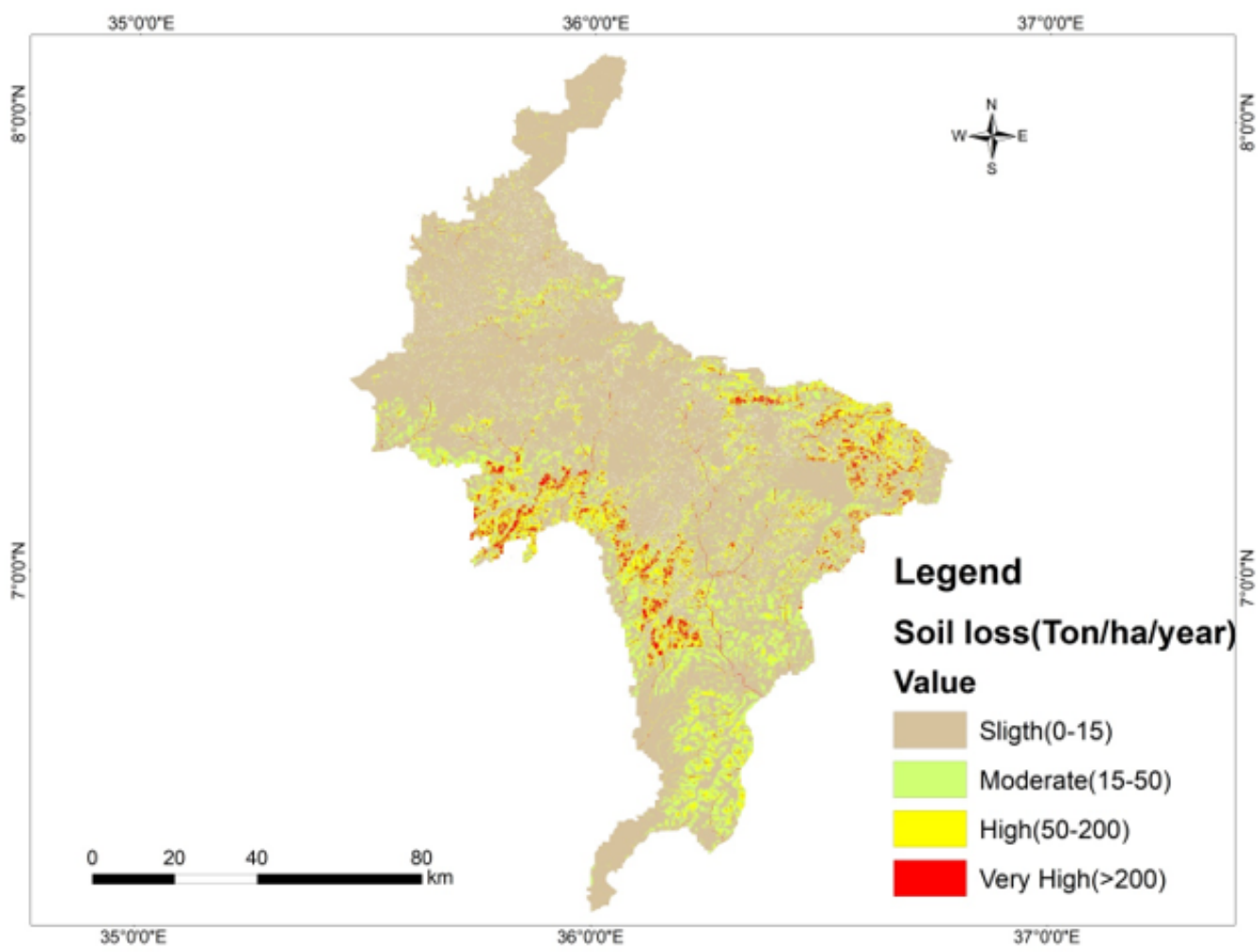

Figure 8

Map depicting spatial variation of soil erosion loss in Kaffa Zone 